\title{
IN MEMORIAM: MOISÉS BÉHAR (1922-2015)
}

\author{
Carlos Ossenbach \\ Orquideario 25 de mayo, Sabanilla de Montes de Oca \\ caossenb@racsa.co.cr
}

$M o i$, as he liked to be called by family and friends, passed away on February 14th in Jerusalem, where he had enjoyed the last years of his life in the loving care of his daughter Jacqueline. At the age of 92, he now rests in peace in the Mount of Olives Cemetery. After Otto Mittelstaedt (1919-2000) and Otto Tinschert (1915-2006), Guatemala's orchidology has now lost the third of its founding fathers.

Moisés Béhar Alcahé was born on August 28, 1922 in Huehuetenango, Guatemala, as the third of six children of Elías Béhar and his wife Eugenia, who had emigrated from Turkey in the aftermath of World War I, after the disintegration of the Ottoman Empire (Fig. 1A).

Elías Béhar set up business as a tailor and cloth importer in San Pedro Sacatepéquez, in the Department of San Marcos. A small village with a predominant indigenous population at an elevation of over 7,200 feet, San Pedro saw Moisés grow up and finish his primary education at the local school. He then went to high school in the neighboring city of Quetzaltenango. It was his childhood and adolescence in these pristine mountains of Guatemala's highlands that marked his life and character, for Moi developed a close and intimate relationship with nature.

After finishing high school, and wishing to study medicine, Moisés moved to Guatemala City against the will of this father, who wanted him to go into the family business. He graduated as Surgeon and Physician in 1949 at the University of San Carlos and in 1954 married Beatriz Aldana, daughter of a well-known Guatemalan physician and former Minister of Public Health (Fig. 1B). Moi and Beatriz had three children: Michelle (1955), a plastic artist who now lives in Curitiba, Brazil; Jacqueline (1957) a translator living in Jerusalem; and Henri (1958), an architect who serves as director of a prestigious school in Switzerland.

Moisés Béhar made a brilliant career in medicine. $\mathrm{He}$ specialized in Pediatrics and Hepatology at the
University of Paris in 1951 and received a Master's Degree in Public Health from Harvard University in 1960. After working as Chief of the General Direction of Public Health from 1951 to 1953 he began his career as consultant in pediatrics for the Institute for Nutrition of Central America and Panama (INCAP), being named in 1957 as Assistant Director and in 1961 as Director, a position he held until 1974.

In 1975, Moisés Béhar moved to Geneva, Switzerland, to occupy the position of Chief of the Department of Nutrition of the World Health Organization.

During his professional life Moisés Béhar occupied important positions. He was President of the Guatemalan Pediatrics Society from 1956 to 1957, Vice-President of the American Society of Public Health from 1966 to 1967, received the Bronfman Prize from the American Society of Public Health in 1968, was installed as a full member of the Guatemalan Academy of Sciences in 1973, decorated by the Government of Guatemala with the order Rodolfo Robles in 1994 and again with the National Order of Pedro de San José de Bethancourt in 2007.

$\mathrm{He}$ published over 150 articles and chapters of books, mostly on infantile malnutrition, and gained international reputation for the development, conceptualization, testing and trials, together with a group of scientists, of INCAPARINA, a formula consisting of a mixture of predominantly vegetable protein made from entirely indigenous materials, designed to fight mal-nourishment amongst the lowincome population of Central America. INCAPARINA derived its name from INCAP, the institute of which Moisés Béhar had been Director for so many years, and HARINA, the Spanish word for flour. In the words of Béhar, "for many of our problems the solutions cannot be found in the textbooks, nor will they be sought for by other countries." 

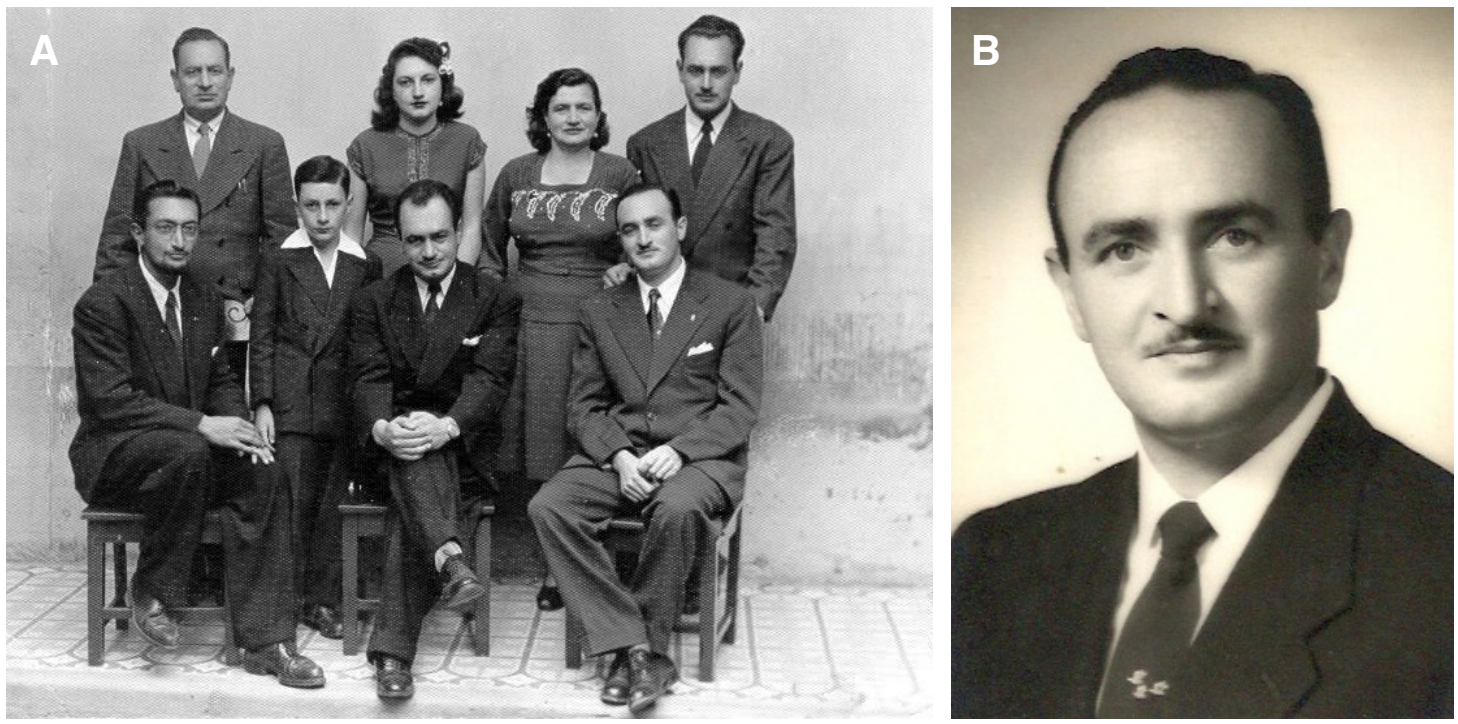

Figure 1. A. Elías Béhar with his wife Eugenia Alcahé and six children. Moisés Béhar is the first sitting on the right (early

1950’s). B. Moisés Béhar (1922-2015) (early 1950’s).

His interest in orchids began early, and became almost a second profession as soon as he had established himself as a successful professional and had formed a family (Fig. 3). In 1960, and on the initiative of Moi, six friends devoted to orchids began to meet on a regular basis, and thirteen years later, the Guatemalan Society of Orchidology (Asociación Guatemalteca de Orquideología or AGO) was formally established by its eight founding members. Moisés Béhar became the Society's first President.

Moi dedicated himself to several areas of interest amongst orchids, but in two of them intimately related- he became a noted international expert: the hybridization of orchids of the subtribe Pleurothalidiinae and the photography of miniature orchids long before the advent of digital photographic technology. His lectures on orchid photography where packed to the last seat (Fig. 4). The author was lucky to be able to attend two of them in Soroa, Cuba in 2000 and in San José, Costa Rica in 2001, and retains unforgettable memories of Moi and his generous and charming ways of sharing his enormous knowledge with the common mortals.

His daughter Jacqueline recalls how he fell in love with miniature orchids. When he moved to Switzerland in 1975, he left his large orchid collection in Guatemala. After a while, he could not resist the urge to grow orchids, and so he bought a small greenhouse which he attached to his house. One thing led to another, and so the small dimensions of the greenhouse led to the growing of miniatures. He had to confront many difficulties; the sun in summer scorched his plants, while in winter they froze to death. Again, Moi had great success and overcame all obstacles, ending as Vice-President of the Swiss Society of Orchidology (Groupe de Romandie), to which he inherited all his plants when he returned to Guatemala in 1986. Of Moi's dozens of hybrids, he dedicated two to his daughters: Lepanthopsis Michelle and Pleurothallis Jacqueline (Fig. 5).

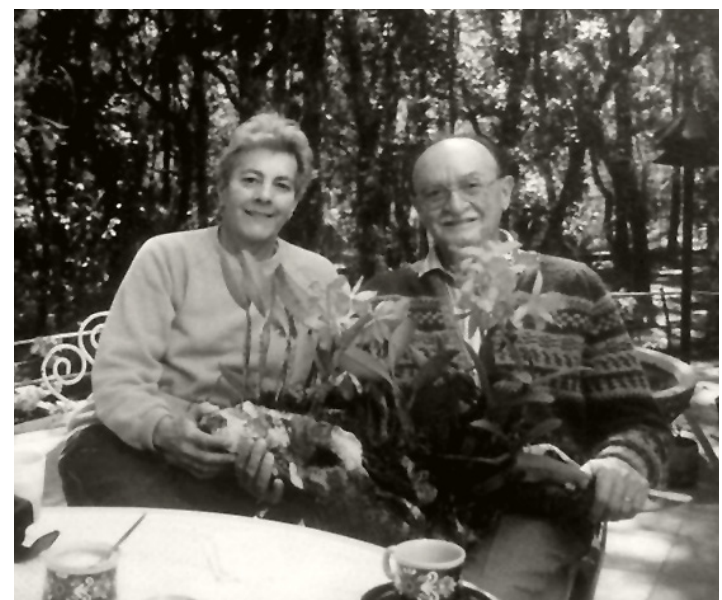

FIgURE 3. Moi and wife Beatriz at their home in Guatemala with beautiful specimens of Guarianthe skinneri. 

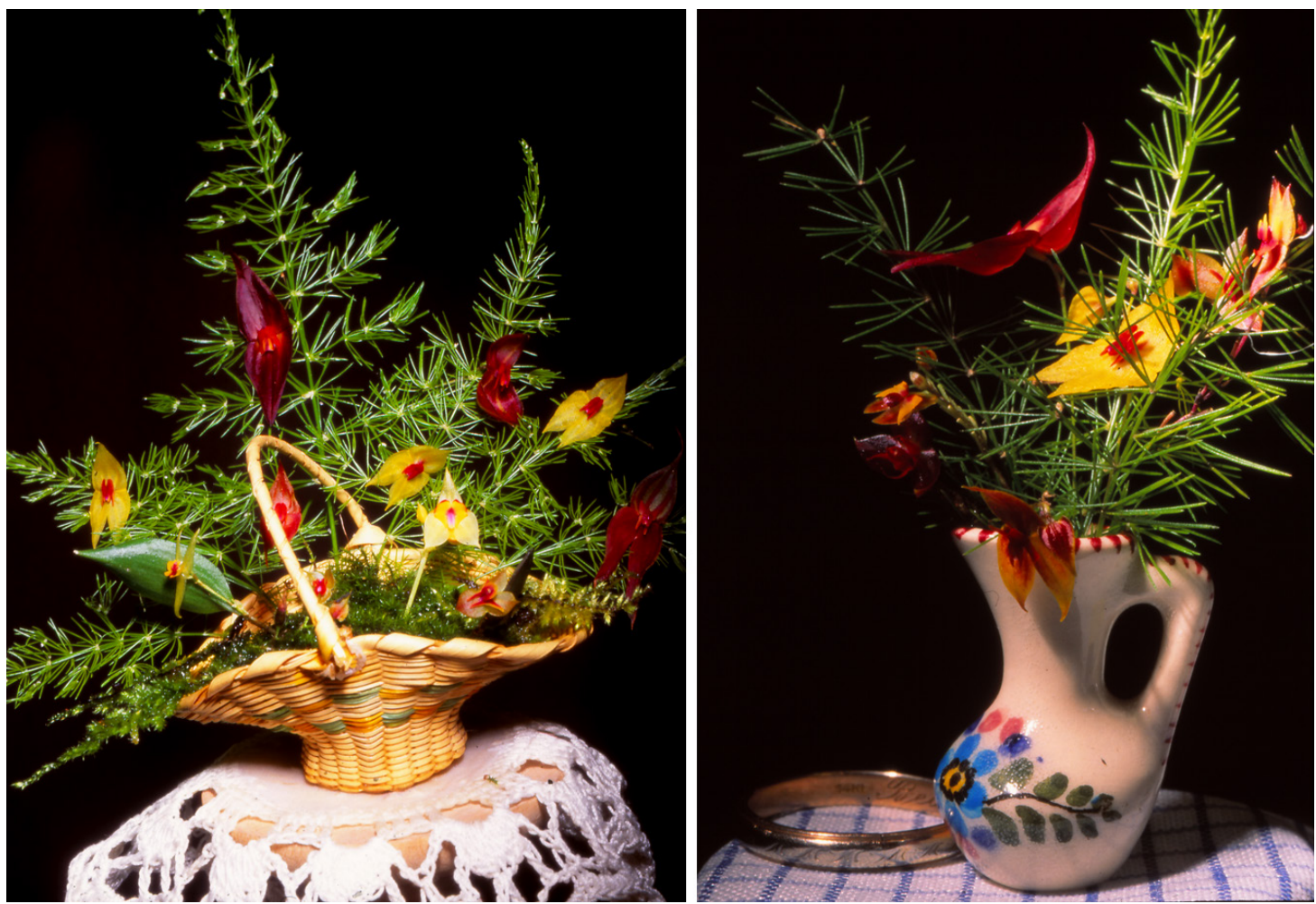

FiguRE 4. Examples of Moisés Béhar's achievements in macro photography. A. Lepanthes flower arrangements \#1. B. Lepanthes flower arrangements \#2 (for scale see wedding ring next to flowers).

An enthusiast of miniature orchids could not live long without crossing the path of the unchallenged world authority on Pleurothalidiinae, Dr. Carlyle Luer. When Luer first came to Guatemala and met Moi for the first time, a life-long friendship began. As doctor Luer remembers: "Moi Behar was one of our best friends. We knew him for over 30 years. I guess it was Lepanthes that brought us together when he retired from Geneva. We visited him and his wife in Guatemala in their home and

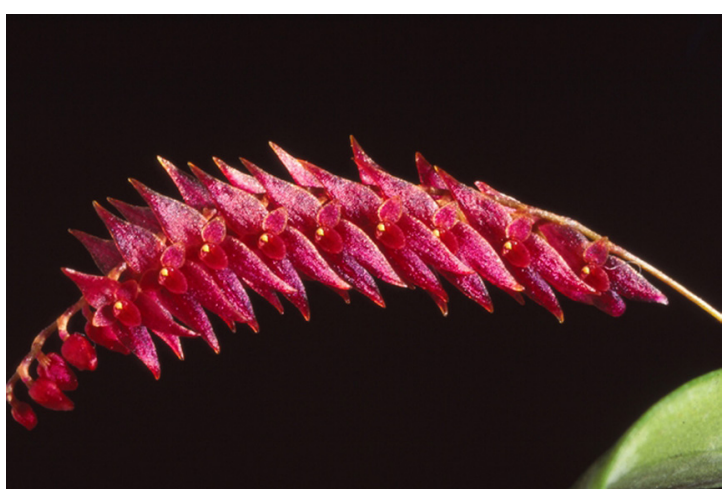

in the field. He had also visited with us in our home in Sarasota. Later, after he lost his wife, he moved to Curitiba where we also visited with him where he was living with his daughter Michelle. Our birthdays were five days apart; I was five days older. We corresponded frequently, so when I did not hear from him since last August, I knew he was not well."

Moi and Luer's friendship yielded a large harvest. Together they contributed to Guatemala's orchidology

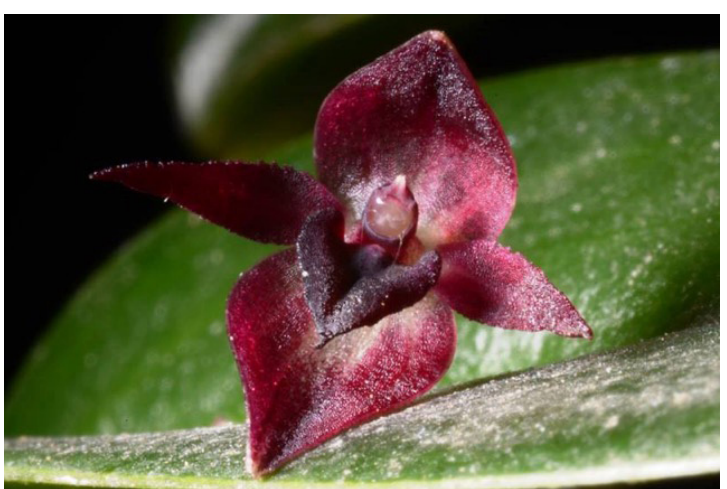

Figure 5. Moisé Béhar's miniature orchid hybrids. A. Lepanthopsis Michelle. B. Pleurothallis Jacqueline. 
TABLE 1. Orchids described by Luer and Béhar.

Dresslerella archilae Luer \& Béhar
Lepanthes almolongae Luer \& Béhar
Lepanthes bífida Luer \& Béhar
Lepanthes chapina Luer \& Béhar
Lepanthes denticulata Luer \& Béhar
Lepanthes empticia Luer \& Béhar
Lepanthes fratercula Luer \& Béhar [Fig. 08]
Lepanthes geniculata Luer \& Béhar
Lepanthes herrerae Luer \& Béhar
Lepanthes ibanezii Luer \& Béhar
Lepanthes juanii Luer \& Béhar
Lepanthes lenticularis Luer \& Béhar
Lepanthes migueliana Luer \& Béhar
Lepanthes mittelstaedtii Luer \& Béhar
Lepanthes noelii Luer \& Béhar
Lepanthes ordonezii Luer \& Béhar
Lepanthes pabloi Luer \& Béhar
Lepanthes pachyphylla Luer \& Béhar
Lepanthes quetzalensis Luer \& Béhar
Lepanthes stenosepala Luer \& Béhar
Lepanthes tecpanica Luer \& Béhar
Lepanthes velifera Luer \& Béhar
Pleurothallis dixiorum Luer \& Béhar

with the description of 23 orchids new to science, all from their beloved Pleurothalidiinae. In addition, Carlyle Luer described another new Lepanthes from Guatemala and named it in honor of his friend as Lepanthes beharii (Tab. 1).

Moi 's grandson Asher, son of his daughter Jacqueline, became in his old days his pupil and companion, his fellow traveler and his 'second pair of eyes'. Asher went with Moi on field trips, climbed for him to the tree tops to bring down the beautiful miniatures, helped him with the determination of the plants, and traveled with him to various world orchid conferences. Today, and thanks to his years with his grandfather, Asher has become another orchid expert. In Asher's words, he not only lost his grandfather, but the only person in the world with whom he could talk on a similar intellectual level. Asher had a son 8 months ago and proudly named him Moshe, Moisés in Hebrew.

Moisés Béhar made another significant contribution to the orchidology of his country. Already in 1993 he had published a small book under the title Orchids of Guatemala, but his major work, in co-authorship with his close friend Otto Tinschert (1915-2006) was the publication in 1998 of Guatemala y sus Orquídeas/

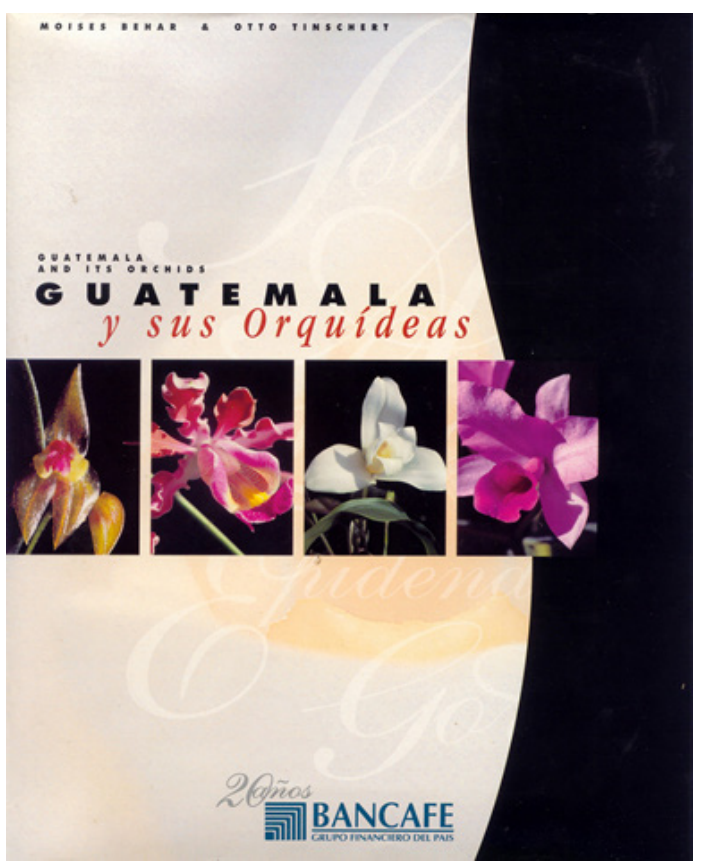

FIGURE 6. Guatemala and its Orchids - Front cover.

Guatemala and its Orchids (Fig. 6), a beautiful masterpiece with descriptions and photographs of 260 species in 100 genera, with additional detailed information about the different life zones of the country. Most photographs were, as could be expected, taken by Moi himself.

Moisés Béhar and his friend Otto Tinschert tried to set in motion a large-scaled orchid conservation project in the northern department of Petén. Defying the internal wars between leftist groups and the Guatemalan Army, Moi and Otto travelled together, trying to convince the lumber industry to save the orchids from the large forest areas that were being cut down and to bring them to an Army base, so that they could be later re-planted in other areas. Unfortunately, the project met with no interest and soon failed.

Disappointed by the tragic situation of the deforestation in Guatemala, and with little hope of detaining it, Moi and Otto began, with a small group of interested friends, to promote the creation of a National Botanical Garden, which could fill in the voids in the areas of research, study, sustainable use and conservation of the country's flora. They worked arduously towards this ideal, convincing 

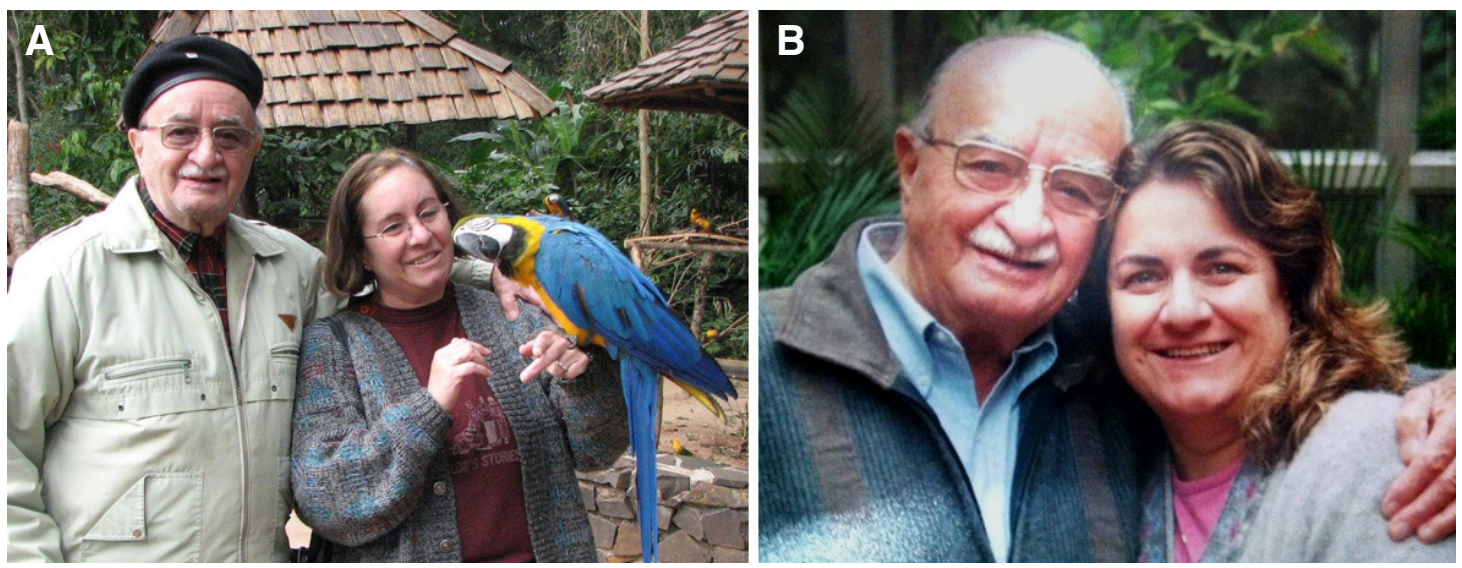

FIgure 7. Moi with daughters Michelle (A) and Jacqueline (B) .

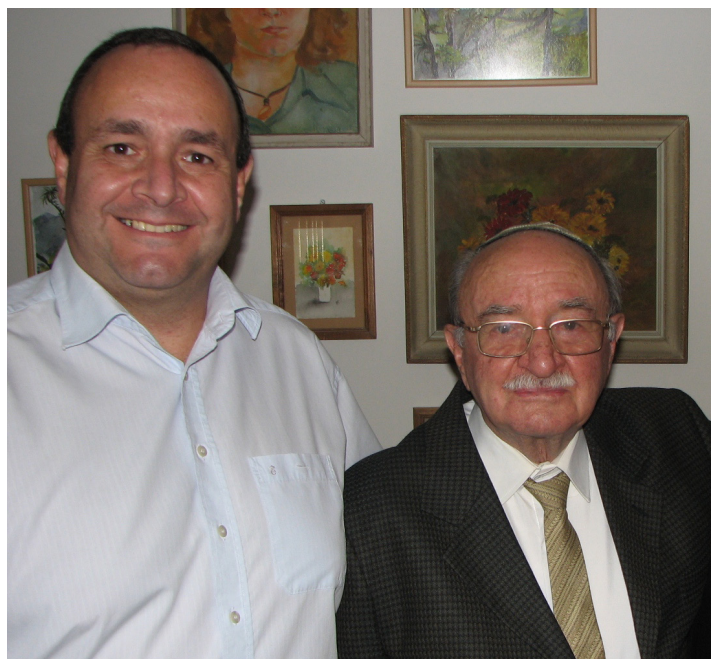

Figure 8. Moi and son Henri.

and motivating universities, foundations and other organizations. This idea has now little hope of it becoming reality.

After living for several years in Brazil with his daughter Michelle (Fig. 7A), in the last years of his life,
Moi moved to Jerusalem with his daughter Jacqueline (Fig. 7B), while he still was able to travel a few times to Geneva, to visit with son Henri (Fig. 8). However, he never would see his beloved mountains of Guatemala again. Generous to his last day, he had donated his large collection of photographs to the Guatemalan Orchid Society, and shared his vast knowledge with anybody who came to him in need of answers, as the author can acknowledge from own experience.

Wonderful doctor, orchidologist, great-grandfather, grandfather, father and friend....

Farewell Moi! Rest in peace!

Acknowledgements. To Jacqueline Béhar, who has valuable insight into her father's life and provided all of the family photos; and to Julio Fonseca, President of the Guatemalan Orchid Society, who contributed with many of Moi's splendid orchid photographs. 